\title{
MANAGERS’ RESPONSE TOWARDS BUSINESS ENVIRONMENT - BEHAVIORAL MANAGEMENT
}

\author{
Ivana Mandysová1, Jana Kubanová1 \\ ${ }^{1}$ Faculty of Economics and Administration, University of Pardubice, Studentská 84, 53210 Pardubice 2, \\ Czech Republic
}

To link to this article: https://doi.org/10.11118/actaun201967051297

Received: 1. 7. 2019, Accepted: 15. 8. 2019

To cite this article: MANDYSOVÁ IVANA, KUBANOVÁ JANA. 2019. Managers' response towards business environment - behavioral management Acta Universitatis Agriculturae et Silviculturae Mendelianae Brunensis, 67(5): 1297-1307.

\begin{abstract}
Article presents the results of testing managers' behavior and response towards business environment. The study develops ideas how to extend current management theory with behavioral approach. Research method is based on in-depth empirical qualitative analysis, results are subject of quantitative verification using statistical methods which allows reaching better results. Research proceeds inductively, it means that new knowledge is generated as outcome and matched to theories. Decisions are examined as responses towards business environment components, correlations and significances between active or passive managers' behavior are demonstrated. Proactive managerial approach is characterized by frequent change and diversification in suppliers, customers, human resources and product portfolio. As a conclusion, managerial response can be interpreted as a product of managers' activity, personal preferences and abilities. The re-orientation towards recognition of active or passive behavior is developed and matched towards current theories. It can be assumed, that the current scientific discussion is potentially relevant in seeking to explain the role of individual manager. In summary, the analysis and the outcomes have proved managers' exceptional flexibility in counteracting actively the shortcomings of external context.
\end{abstract}

Keywords: behavioral management, management, business environment

\section{INTRODUCTION}

The paper examines the managerial behavior practices, his decision making, and active approach. The environmental context influences the nature and the way managers behave. These complex phenomena, acknowledging the style and strength of manager's responses towards environmental components also include their constellation, institutional conditions, firm background and especially managers' own personal characteristics. The role of managers' nature and behavior needs to be investigated. Focusing on this, the study strives to amend management theories with situational behavioral approach. Empirical study tests, whether and how a managers' response, behavior and actual decision making is linked to environmental context.

\section{Statement of Problem}

In management theories, represented by Koontz and Weihrich (2015), there is insufficient space for the behavior of an initiative manager, his decisions and actions under knowledge access. Lawrence and Lorsch (1967) state that classical economic theory neglects the possibility of independent manager to interfere and influence environmental components like labor markets and competitors, suppliers, local legislation, and so on. The explanations of economic processes inside a company are still full of obstacles which result from shortcomings at the theoretical level. Current theories do not take into account individual manager as a human. According to Emery and Trist (2009), neoclassical theories tend to perceive all firms de facto in the 
same way - as black boxes capable of only a limited number of activities and responses to the outside, and their behavior is predetermined by the specific conditions of the surrounding environment.

\section{Theoretical Background}

A traditional theory, perceiving a firm as a set of inputs and outputs, is gradually being replaced by the perception of the company as a set of ties and networks. The stakeholder concept of the firm in the surrounding environment perceives the company with mutual ties and interests of various stakeholders. A firm links its relationship to individual stakeholders with different interests that result in different expectations.

Environment not only influences managers but managers may also influence business environment by contributing to its change. Firm environment consists of different stakeholders, and can be called environment "components" or "factors" such as: location, suppliers, human resources, customers, competition, finance resources, state legislation, etc. Some theorists state also other stakeholders like competitors, mass media, the public, etc.

It is not the purpose of this article to focus on each of stakeholders' components, but to analyze character of managers' responses towards selected components. Legislation framework and informal framework include uncodified society aspects where managers and decision makers are players, constrained, enabled, and impacted by complex characteristics of the business environment. Business environment evokes managers' reactions and their behavior has become an important issue today. A certain group of theories state that the environment supports and stimulates management response, strength and style. Publications on the effects of the environment characteristics on the management style has grown rapidly in the past. Recent empirical researches examine a variety of management styles (Killingsworth et al., 2016). Over the last decades, in the Czech Republic, more and more researches investigate managers' behavior and decision makings in contrast to structural responses to environment conditions (Šebestová, 2007; Koráb and Bumberová, 2013).

In the sixties, the so-called "behavioral school of economic theory" attempts to fill the gap in economic theories. The new approach focuses on economic choices and personal motives in the behavior of entrepreneurs. This category includes such theorist as Simon (1957), Cyert and March (1972). These theories unlike neoclassical proceed inductively, the conclusions are derived from the generalization of empirical observations. Behaviorists describe behavior of managers and then correlate with explanatory factors. When creating theoretical background regarding the manager's behavior, we have become increasingly interested in the managers' decisions and actions in relation to business environment components.
Management theorists like Bingham and Haleblian (2012) question the assumptions of rational behavior of managers. They raise doubts whether the decision of a manager always leads to the fulfillment of the company objectives. They stress that there is no full or sufficient awareness and information. Management theorists therefore change to behavioral approaches. Economists, who are close to sociology, have generated new platform based on behavioral approaches. Behavioral approaches respect the influence of an environment where there is risk and uncertainty. Preferences of managers and entrepreneurs influence the process of location and decision-making (Child, 1972).

Kahneman (2012) suggested that managers instead of seeking intellectual decisions should make decisions in accordance with heuristics. The manager is limited by the time he has to decide, as well as the limited amount of information. Kahneman (2012) introduced a specific way of managerial decision-making and simplifying the decision-making process where rule of thumb is the solution. Management heuristics is the manager's mental approach in solving problems.

Behavioral management theory allows for uncertainty and irrationality. In reality, managers are rarely able to use the optimization calculations. They are often replaced by simple procedures, routines, experience or imitation. These methods are summarized in the concept of heuristics. Heuristic take consciously not optimal solution, but acceptable solution (Bingham and Haleblian, 2012). Applying heuristic approach may be useful in particular in cases where the optimization calculation requires additional cost of information, time and resources. These are called transaction costs. By a heuristic approach, the manager does not intentionally choose the optimal solution, but acceptable and satisfactory solution (Killingsworth et al., 2012). The use of a heuristic approach was examined Killingsworth, he suggested to use heuristics in cases where calculating the optimal variant requires high costs for information, time and finance, i.e. transaction costs. Heuristic approach is a compensation for the deviation from the optimum.

Transaction costs are linked with Williamson. Williamson's main contribution can be seen particularly in the detailed definition of the nature and sources of transaction costs (Williamson, 1973). In accordance with the basic premise, companies try to minimize their total costs, which, however, consist of both production costs and the transaction costs. The basic assumptions on which the theory is based is bounded rationality and opportunism. Bounded rationality means that human rationality is limited to some extent, speaking about exploring the mind, learning, memory. Manager does not have the ability to assimilate all available information.

Allen Pred (1967) improved the existing location theory by incorporating the phenomenon of 
imperfect behavior, incomplete knowledge and other psychological variables. Pred's behavioral critique of the classical theory is actual and very clear. His views are based on the ideas of satisfactory behavior, imperfectly informed managers who make the decisions. In Pred's views there predominate abilities and actions of a manager over environmental factors entrepreneurs.

The gradual changes and replenishment of classical theories into new management theories have not yet resulted in a more active role for the manager and his decisions making under access to knowledge and information coming from outside (Vodák and Strišš, 2005). A new theory, recognizes that events indeed are rarely controlled. With neoclassical theories and modern management theories, the arsenal of approaches has not been exploited, yet. There are emerging approaches by Dill (1962), some of which directly contradict the premise of the supremacy of the environment. According to these approaches, the forces that control the management and operation of the firm and its success cannot be limited only by the limits of the environment. They are more likely to be within the firm and its leadership style.

\section{Aim of the Study}

The main aim of the study is to analyze the manager's behavior under environmental context. It is the purpose to link manager's s individual perceptions and activity to his specific response as the contra-reaction to current situation in order to eliminate negative effects or exploit possible advantages. The analyses focused on how managers change their style scaling from passive to active one in response to perceived environmental pressures, constraints and competition. Competitive pressures, prices, location conditions, human resources, and others were taken into consideration. Is manager active enough in overcoming obstacles? And does his activity result in success? Research taps real forces that have an impact on manager's decisions and actions. According to Šebestová (2007), these forces are endogenous and should be investigated. Accordingly, behavioral and contextual approach is used.

\section{MATERIALS AND METHODS}

Method of presented study analyses the behavior of managers and then correlates these to explanatory factors to the components of the environment, matching to relevant management theories. Behaviorists do not examine how managers should behave, but rather how they actually behave. Dichotomous managers' behavior typology was used: active versus passive managers' responses towards the environment. The environment has been divided following stakeholder concept into 5 components. Research proceeds inductively, it means that new knowledge is generated as outcome and matched to theories. Research is based on the qualitative method and is focused on managers, owners and managers of micro and small firms, it analyses the real reactions of managers and their motives. Qualitative research method involves the collection and analysis of qualitative data. Conclusions are derived from the generalization of empirical observations. According to Silverman (1997) qualitative research is a process of seeking understanding of the problem. The researcher creates a complex, holistic image, analyzes the different types of texts, and explores under natural conditions. In order to verify and critically examine theoretical models quantitative verification is used. This approach enables to achieve a more accurate result.

Argument for choosing qualitative research method was the intention to find the essence of a phenomenon. Silverman (1997) defines qualitative data as detailed, specific descriptions of object based on direct observation, interviews, and case studies. Inductive method begins with an observation that seeks for regularities verified by further testing. The investigated firms come from the Pardubice region where quantity of entrepreneurs and legal entities exceeds 167 thousands. Due to substantial number, the sample cannot be considered as representative from statistical point of view. Silverman defines saturation as a point of representativeness. Research is considered to be saturated when obtained information keep repeating and data remain the same.

Another argument is long term research. Development over time and changes allowed to examine managerial decisions and to correlate them to environment.

Mathematical or statistical representativeness is applied by mathematical method. The relationship between the business environment components and the managers' behavior is demonstrated by independence test. With the independence test, we tested the null hypothesis that the components of the business environment (random variable $\mathrm{X}$ ) and the behavior of the manager (random variable Y) are independent (Kubanová and Roudný, 2008).

Let us denote $n_{i, j}$ the number of random selection values that are equal to $\left(x_{i}, y_{j}\right)$.

Next:

$$
n_{i \bullet}=\sum_{j=1}^{s} n_{i j}
$$

and

$n_{\bullet j}=\sum_{i=1}^{r} n_{i j}$ (marginal frequency). 
The test criterion shape is:

$$
\chi=\sum_{i=1}^{r} \sum_{j=1}^{s} \frac{\left(n_{i j}-\frac{n_{i \bullet} \times n_{\bullet j}}{n}\right)^{2}}{\frac{n_{i \bullet} \times n_{\bullet j}}{n}} .
$$

Assuming the hypothesis is valid, the random variable $\chi$ has asymptotically $\chi^{2}$ probability distribution with ( $\mathrm{r}-1)(\mathrm{s}-1)$ degrees of freedom. The critical area is defined by:

$W=\left\{\chi: \chi>\chi_{\alpha,(r-1) \times(s-1)}^{2}\right\}$.

The critical boundary $\chi_{\alpha,(r-1) \times(s-1)}^{2}$ is found in tables $\chi^{2}$ of probability distribution.

Another method is principal component analysis, which shows the role of the components in selected firms (Kubanová and Roudný, 2008). The method helps to solve the problem of data reduction and finding the relation between observed variables. It allows to find such a set of linear combinations of original variables that retain as much information as possible, but number of its elements will be smaller and consequently the number of original variables, i.e, the original m-dimensional vector is replaced by a smaller number of its coordinate linear functions called main components.

\section{Collection and Analysis of the Data}

The investigated managers are entrepreneurs conducting a business under trade license, managers of micro or small firms. Direct personal confrontation with the examined object is an argument for the reliability. The procedure of empirical data collection was as follows: data were obtained by interviews with entrepreneurs (17), managers or managers as owners of businesses (8). Interviewed managers are a versatile group of people, all with valuable and comprehensive insights of their firm genesis, development and daily matters. It is important to receive information from manager who is aware of all firm history and relations towards all stakeholders, customers, suppliers, human resources, etc. The smaller firm, the more perfect information and more detailed knowledge.

The NACE proportionality was assured by calculating percentage of NACE in the Czech republic and choosing adequate number in Pardubice region so that the empirical sample can be viewed as representative with NACE proportionality (Počty podnikatelů a živností dle krajů, online).

The transition process which started 30 years ago included restitution of confiscated property and required not only changes to the economic system, but also changes in attitudes toward private business. Former bankrupt state owned firms served as a source for customer portfolios, technical skills, ideas, and educated experts; many firms have been founded on these bases. Some of firms emerged as new idea. The research of 25 firms was carried out over the past 10 years (20082018), mapping maximum years of firms' history Thirty years means a sufficiently long period for generational change, which makes this research interesting.

There were an informal semi-structured interviews. Set was the framework of interview, questions were directed to crystallize the situations that particularly affected the managers' reactions. Information that triggers action comes from the environment. Their dynamics and causal mechanisms were emphasized. What kind of decisions do active managers take? And how they are manifested externally? What is the situation in the environment component? What are the problems forming managers' active approach or are they threatening or risky? How is problem

I: Number of sample firms according to NACE

\begin{tabular}{lc}
\hline \multicolumn{1}{c}{ CZ-NACE classification } & Examined sample - number of firms \\
\hline Agriculture, forestry and fishing & 1 \\
Mining and quarrying & 1 \\
Manufacturing & 9 \\
Electricity, gas, steam and air conditioning supply & 1 \\
Construction & 2 \\
Wholesale and retail trade; repair of motor vehicles and motorcycles & 5 \\
Transportation and storage & 1 \\
Accommodation and food service activities & 1 \\
Information and communication & 1 \\
Professional, scientific and technical activities & 1 \\
Administrative and support service activities & 1 \\
Other services activities & 1 \\
\hline
\end{tabular}


perceived by a manager, and what is his response? The interview searched for links and moments particularly affecting managers' behavior (active/ passive). Questions were aimed to identify the idea of starting a business (where, when, why), they developed gradually as managers described the development of their firms. Questions searched for moments that influenced managers' behavior, especially with respect to the five components: Location, Suppliers, Human Resources, Customers, State and finance. Selected environment components affect a manager and evoke his need for a decision and subsequent choice of action. These components are in accordance with theorists like Lawrence and Lorsch (1967) and Emery and Trist (2009). Respondents were recorded and then the text was literally transcribed. To achieve confidentiality the names were replaced with identification codes. 300 pages of text have been obtained.

Examples: "We were looking for a way to introduce and expand our core business awareness and present the benefits of rotomolding technology. We were afraid that the common way of establishing a contact like mailing to the purchasing department may not bring desirable results, official would throw letter into the trash. We decided for rather unusual channel: to write a short letters right to the directors of large companies."

"These were times of hard work full of enthusiasm and personal involvement. I felt like in the paradise dream. We were all fully interested in the business and technological details, we were searching for any, even foolhardy information or knowledge."

Collected text was organized and integrated properly by prevailing assumptions and matched to theoretical patterns. Managerial behavior practices statements were grouped and connected to managerial theories in order to confirm or refute theories. Subsequently, the data were processed and strongest relations of dependence were identified and analyzed.

Data - all collected and corrected text - were organized into association table and were grouped into five aforementioned areas (A, B, C, D, E). The empirical study surveyed 25 companies and the text confirms or refutes identified statement. Statements were labeled as AH1, AH2, BH1, BH2, CH1, CH2, DH1, DH2, EH1, EH2. In case claim was confirmed, it corresponds to active manager behavior and it has been assigned a value of $1(\mathrm{AH} 1=1, \ldots)$. In case claim was not confirmed, it corresponds to passive manager behavior and it has been assigned a value of $0 .(\mathrm{AH} 1=0, \ldots)$. The statements come from environment components and are designed to be appropriate in relation to recent theoretical outcomes. The statements focus on behavioral management approach and stress active role of a manager.
Environmental components:

A. Localization, business growing in relation to the environment and growing in the region.

B. Suppliers.

C. Human Resources.

D. Customers, market environment.

E. Financial environment and state.

\section{A. Managerial Behavior: Location, Firm Growth}

AH1: manager successfully tackles location obstacles but disadvantageous location increases his cost, (transactional costs).

AH2: manager is successful and firm grows. The growth causes creation of new supra-regional relations.

\section{B. Suppliers}

BH1: manager successfully tackles problems with suppliers, he revises firm suppliers (in quality, prices, reliability..) often and changes them subsequently.

BH2: manager replaces local unreliable suppliers by new supra-regional ones.

\section{Human Resources}

CH1: despite the difficulties manager finds and acquires qualified employees.

$\mathrm{CH} 2$ : manager decides to dismiss employees when it is necessary, e.g. due to the crisis.

\section{Customers, Market}

DH1: manager is able to overcome unfavorable market conditions in the local environment.

DH2: in unfavorable local market environment active manager proves stronger activity in order to become more competitive.

\section{E. Financial Environment and State}

EH1: local availability of sources is limited, we use mainly own sources.

EH2: we got subsidies to support the business.

\section{RESULTS}

Independence test: The relationship between the business environment components - $\mathrm{AH}$ localization, BH suppliers, $\mathrm{CH}$ human resources, DH customers, and the financial and legislative environment $\mathrm{EH}$ on the one hand and the behavior of the manager responding to the situation either actively or passively - was evaluated on a scale of 0 or 1.

The test criterion value was calculated: $\chi=16.4$, with critical value, i.e. rejection point at significance level $\alpha=0.05$ and four degrees of freedom is 9.49. Test criterion value has fallen into critical area, zero hypothesis is rejected, we can claim that X and Y are not independent. That is the relationship between business environment components and managerial behavior has been demonstrated.” 
II: Association table confirming or refuting behavioral management statements grouped into five aforementioned environment components $(A, B, C, D, E)$

\begin{tabular}{|c|c|c|c|c|c|c|c|c|c|c|}
\hline Statement Company & $\mathrm{AH} 1$ & $\mathrm{AH} 2$ & BH1 & $\mathrm{BH} 2$ & $\mathrm{CH} 1$ & $\mathrm{CH} 2$ & DH1 & DH2 & EH1 & $\mathrm{EH} 2$ \\
\hline 01 & 1 & 1 & 1 & 0 & 1 & 0 & 1 & 0 & 0 & 1 \\
\hline 02 & 0 & 0 & 1 & 0 & 0 & 0 & 1 & 1 & 0 & 0 \\
\hline 03 & 0 & 1 & 1 & 1 & 0 & 1 & 1 & 1 & 1 & 0 \\
\hline 04 & 1 & 1 & 1 & 0 & 0 & 1 & 0 & 1 & 1 & 0 \\
\hline 05 & 1 & 1 & 0 & 1 & 0 & 1 & 1 & 0 & 0 & 0 \\
\hline 06 & 0 & 0 & 0 & 1 & 1 & 0 & 1 & 0 & 0 & 0 \\
\hline 07 & 0 & 1 & 0 & 1 & 1 & 1 & 1 & 0 & 0 & 0 \\
\hline 08 & 0 & 1 & 1 & 1 & 0 & 0 & 1 & 0 & 0 & 1 \\
\hline 09 & 1 & 1 & 0 & 0 & 0 & 0 & 1 & 1 & 1 & 0 \\
\hline 10 & 0 & 1 & 1 & 1 & 0 & 0 & 1 & 0 & 1 & 0 \\
\hline 11 & 0 & 1 & 1 & 1 & 1 & 0 & 1 & 1 & 1 & 0 \\
\hline 12 & 1 & 1 & 0 & 1 & 1 & 0 & 0 & 0 & 0 & 1 \\
\hline 13 & 0 & 1 & 0 & 1 & 1 & 0 & 1 & 1 & 1 & 1 \\
\hline 14 & 0 & 1 & 0 & 0 & 1 & 0 & 1 & 1 & 0 & 1 \\
\hline 15 & 0 & 1 & 0 & 1 & 1 & 1 & 1 & 1 & 0 & 1 \\
\hline 16 & 0 & 1 & 1 & 1 & 0 & 0 & 1 & 1 & 0 & 0 \\
\hline 17 & 0 & 1 & 1 & 1 & 0 & 1 & 1 & 1 & 0 & 0 \\
\hline 18 & 0 & 0 & 0 & 0 & 0 & 1 & 0 & 0 & 0 & 1 \\
\hline 19 & 1 & 1 & 1 & 1 & 1 & 0 & 1 & 1 & 0 & 0 \\
\hline 20 & 0 & 1 & 0 & 1 & 0 & 0 & 1 & 1 & 1 & 0 \\
\hline 21 & 1 & 1 & 1 & 1 & 0 & 1 & 1 & 0 & 1 & 0 \\
\hline 22 & 0 & 0 & 1 & 0 & 1 & 0 & 0 & 0 & 0 & 0 \\
\hline 23 & 1 & 1 & 0 & 1 & 0 & 0 & 1 & 1 & 1 & 0 \\
\hline 24 & 1 & 0 & 1 & 1 & 1 & 1 & 1 & 0 & 0 & 0 \\
\hline 25 & 1 & 1 & 1 & 1 & 1 & 1 & 1 & 1 & 1 & 1 \\
\hline Total 0 & 15 & 5 & 11 & 7 & 13 & 15 & 4 & 11 & 15 & 17 \\
\hline Total 1 & 10 & 20 & 14 & 18 & 12 & 10 & 21 & 14 & 10 & 8 \\
\hline
\end{tabular}

\section{Correlation Sheet}

Next important step is to describe this correlation more closely and possibly to determine its tightness. This is done by correlation analysis methods. If the random variables $\mathrm{X}$ and $\mathrm{Y}$ are not independent, their correlation must be quantitatively expressed. A correlation coefficient is used to express the degree of dependence. Relevant but less known than Pearson's method of correlation analysis is the use of a tetrachoric correlation coefficient. Tetrachoric correlation coefficient theory: Suppose that $X, Y$ are dichotomous, i.e. that they are 0 or 1 , etc. The values of the ordered pairs $(X, Y)$ are arranged in a table and denoted by A number of pairs $(0,0)$, B number of pairs $(0,1)$.

$K=A D / B C$
Tetrachoric correlation coefficient:

$R_{\text {tetr }}=\cos \left(\frac{\pi}{1+\sqrt{\frac{A D}{B C}}}\right)$.

To test the significance of the tetrachoric correlation coefficient, it is permissible to use the same critical value as at the Pearson's coefficient,

III: Values of the ordered pairs

\begin{tabular}{ccc}
\hline $\mathrm{x} / \mathrm{y}$ & 0 & 1 \\
\hline 0 & $\mathrm{~A}$ & $\mathrm{~B}$ \\
1 & $\mathrm{C}$ & $\mathrm{D}$ \\
\hline
\end{tabular}


IV: Tetrachoric correlation coefficient - matrix

\begin{tabular}{|c|c|c|c|c|c|c|c|c|c|c|}
\hline & AH1 & $\mathrm{AH} 2$ & BH1 & BH2 & CH1 & $\mathrm{CH} 2$ & DH1 & DH2 & EH1 & EH2 \\
\hline AH1 & 1 & & & & & & & & & \\
\hline AH2 & 0.61 & 1 & & & & & & & & \\
\hline BH1 & 0.25 & -0.42 & 1 & & & & & & & \\
\hline BH2 & 0.49 & -0.17 & 0.27 & 1 & & & & & & \\
\hline CH1 & 0.13 & -0.52 & -0.13 & -0.38 & 1 & & & & & \\
\hline $\mathrm{CH} 2$ & 0 & -0.61 & -0.25 & -0.49 & -0.13 & 1 & & & & \\
\hline DH1 & 0.68 & 0.11 & 0.51 & 0.27 & 0.60 & 0.68 & 1 & & & \\
\hline DH2 & 0.25 & -0.42 & 0 & -0.27 & 0.13 & 0.25 & -0.51 & 1 & & \\
\hline EH1 & 0 & -0.61 & -0.25 & -0.49 & -0.13 & 0 & -0.68 & -0.25 & 1 & \\
\hline EH2 & -0.14 & -0.69 & -0.37 & -0.59 & -0.26 & -0.14 & -0.75 & -0.37 & $-0,14$ & 1 \\
\hline
\end{tabular}

i.e. 0.396 critical value at the significance level $\alpha=0.05$. The correlation coefficient values in bold indicate the existence of a correlation relationship: If the correlation coefficient is positive, the values of the both two variables increase. In the case of a negative correlation coefficient, the values of one variable increase and the other decrease.

A positive statistically significant correlation coefficient was found between variables AH1 and $\mathrm{AH} 2, \mathrm{AH} 1$ and BH2, AH1 and DH1, BH1 and DH1, $\mathrm{CH} 1$ and DH1, CH2 and DH1. These results can be interpreted as follows:

- When active managers succeed to tackle obstacles of disadvantageous location, they cannot avoid additional costs, but they are aware of transactional costs. This does not stop them from growing supra-regionally (Williamson, 1987).

- When active managers succeed to tackle obstacles of disadvantageous location, at the same time they resolve problems with suppliers, like bad quality, high prices, weak reliability. Managers find new suppliers providing better services on supraregional level.

- When active managers succeed to tackle obstacles of disadvantageous location, they reach stronger position on the market, become more competitive on supra-regional level.

- Active managers successfully tackle problems with suppliers by quitting suppliers with bad quality, high prices, low reliability. Managers change subsequently suppliers and this helps them to become more competitive and reach better market position.

- Managers can overcome unfavorable market conditions in the local environment by acquiring qualified employees.

- Managers can overcome unfavorable market conditions in the local environment by dismissing employees in situation when it is necessary.

A negative statistically significant correlation coefficient was found between variable $\mathrm{AH} 2$ and most other variables, $\mathrm{BH} 2$ and $\mathrm{CH} 1, \mathrm{CH} 2, \mathrm{EH} 1, \mathrm{EH} 2$, and DH1 in relation to DH2, EH1, EH2.

- When manager does not tackle the problems with local suppliers, he has to switch to supra-regional level. By this he can ensure firm growth.

- When manager cannot acquire qualified employees locally, he has to switch to supraregional level. By this he can ensure firm growth.

- When manager does not decide at the right time to dismiss his employees, he has other options like turnover growth or switching to supra-regional level. This may lead to firm growth.

- Manager does not need to use his own financial sources when there is good financial availability. This can lead to firm growth.

- Active manager does not need to get subsidies in order to ensure firm growth.

- In extremely unfavorable environment even very active manager does not overcome bad local market conditions. It can be extremely difficult and it may require strong action.

- Even very active manager cannot tackle unfavorable conditions of the local environment when local finance availability is limited.

- Even very active manager cannot tackle unfavorable conditions of the local environment when he does not receive subsidies to support business.

\section{Principal Component Analysis}

Principal component analysis finds a set of linear combinations of the original variables that retain as much data information as possible. It shows the role of the first and second components in analyzing managers' behavior of the selected firms. The main components are independent of each other and are ranked according to the extent to which they contribute to explaining the total dispersion of the original. 


\section{Principal component analysis}

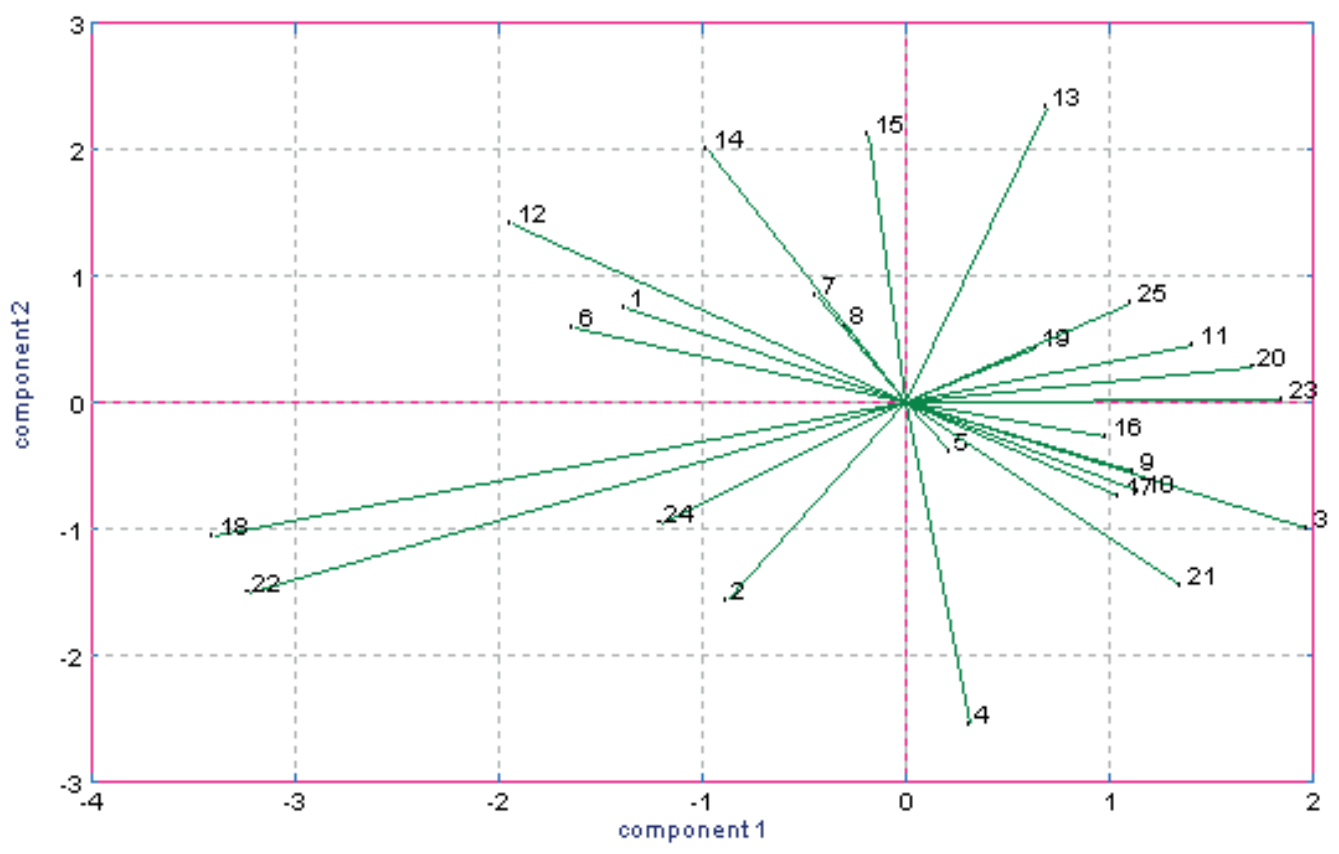

1: Principal component analysis

In Fig. 1 Component 1 of factor analysis means "active manager anticipates obstacles" and Component 2 of factor analysis means "manager is aware of bounded rationality and uses heuristics in decision making”. Factor analysis components were chosen in order to express behavioral approach of sample managers.

- The first and second principal components take positive values for firms 11, 13, 19, 20, 23, 25. Majority of managers' answers are positive. These firms come from retail and wholesale NACE classification. Managers of firms flexibly change the subject of sales and purchase, can adapt quickly to new market conditions. They acquire enough information, and decision making by the heuristic is common for them. Limited rationality is not a burden for them. They do not face the localization disadvantage.

- The first positive and second negative principal component values for firms 3, 4, 5, 9, 10, 16, 17, 21. Four firms come from manufacturing industry, one from transportation industry, one from wholesale and two from construction industry. These industries reported growth over last decade. Behavioral management is an advantage, manager can take advantage of the industry environment and this helps firms to maintain stability.

- The first negative and the second positive principal component value for firms 1, 6, 7, 8, 12, 14, 15. It is a diverse group of businesses and managers use behavioral practices to imitate competition or to change suppliers and customers. They are both small craftsmen and farms.

- Both negative principal components values for firms 2, 18, 22, 24. Three firms are micro-sized, having just one self-employee. Small firms, almost by its nature, anticipate problems because they create smaller and less complex kind of relations in its environment than the bigger ones. These small firms use often imitation of competitors but face the smaller pressure from the environment so they do not bear big risk by using heuristics.

\section{DISCUSSION}

In the research of manager behaviour and decision-making, attention was focused on actions and counteractions (Sener, 2012). It was proved that managers are not able to react to every obstacle they encounter. Sometimes they react in an inadequate way. The article outcomes does not aim to depict the managers are able to resolve all the obstacles they face in environment. The intention is just to highlight that managers need not be at the mercy of a situation as implied by most research.

Managers on higher levels tend to delegate decision-making to lower firm levels that more closely interface with an environment (Mandysová, 2019). As Myšková and Doupalová (2015) state, it enables manager to remove obstacles in time or deal more effectively with risk management and competitive pressures. This will ensure greater flexibility in dealing with perceived pressures. 
Behavioral management (Simon, 1957) is directly affected by the limited determinants of the environment such as sufficient demand, availability of suppliers, human resources and finance sources in the region.

Managers decide following their personal preferences, decision-making according to Kahneman (2012) is a product of personal preferences and characteristics, limited rationality, risk perception. In accordance with Killingsworth et al. (2016), due to of lack of information, managers decide by mental shortcut, they imitate, using heuristics. There are other decision-making factors such as manager's intelligence or perception accuracy (Mandysová, 2019). It can happen that manager acts in haste. The manager decides affectionately, manager is influenced by emotions and mood more than experience.

Manager actively responds to the environment. Managers are able to take advantage of the environment and largely benefit from it. Some managers were forced to develop intense activity and pressure on its disadvantageous environment (Sener, 2012). If they do not meet their needs in the nearest environment, they look for it in the one creating supra-regional ties.

Regarding firm size, smaller firms more often recur to evasion and avoidance strategies, because their smaller resource base would not allow them to comply with the demands of the market. Managers prefer locations and places known to them, in which they have their personal background, family, friends (Pred, 1967; Child, 1972). Managers practice entrepreneurial networking to use personal contacts for firm purposes (Vodák and Strišš, 2005). This involves friends and acquaintances being tied together in a web in order to facilitate access to commodities and services that are in shortage. For small firms, networking can facilitate daily business operations, such as dealing with partners, human resources of state authorities. Stable and business environment can reduce uncertainty and risk for managerial action.

The behavior of managers is regulated by legislation like tax code, labor code as well as contract and bankruptcy legislation impacts a firm functioning, property rights, family policy and public and social policies (Provazníková, 2009). State and pronouncements and actions of its official representatives also impact values of society and of the stakeholders' environment.

It can happen that environmental deficiencies can create conditions for managers' pro-active steps (Vodák and Strišš, 2005). It can include even opportunistic behavior like black market employment, moving business address aiming to tax avoidance or evasion, sometimes even bribes for tax officials (Hafiza and Ismailb, 2005). Managers' actions fill the gaps by exploiting opportunity of malfunctioning of surrounding environments. Seize opportunities by active managers showed a high level of sensitivity and responsiveness to the needs of their business (Dill, 1962). Where environmental component is characterized by major deficiencies, it may be indicative for chances of an active managers' behavior or threats for passive managers' behavior.

Managers are forced to accept proactive approach as a necessary part of their attempt to survive (DeNisi, 2011). Active managers behave in order to facilitate daily business operations, adapt to external conditions but this involves additional cost, transactional costs. Williamson (1973) states that opportunism is only the assumption that participants in economic life must count the eventuality of occurrence of opportunism in the behavior of their partners, subordinates or superiors.

\section{CONCLUSION}

Behavioral management theory (Simon, 1957; Cyert and March, 1972) can provide an appropriate framework because of its emphasis on the manager as individual with its human characteristics. This draws attention to the potential role of manager as change agents rather than simply being passive recipient of the classical management patterns (Esogwa, Chládková and Žufan, 2017). As a consequence, it is suggested that the management theory as usually applied needs to be extended to take into account behavioral approach. This is demonstrated with specific reference to business environmental components, which impacts on managerial behavior as well as, being affected by it (Emery and Trist, 2009).

Active or passive behavior impacts the ability to use the resources that can be mobilized and exploited. The basic principles of management are similar regardless of environment although the meaning and understanding of managerial behavior is specific to mangers' activity. Particular situations may lead to differences in managerial behavior. There must be a specific interplay and balance between individual managers' behavior and the external environment, which instantly goes through changes. All this underlines the importance of recognizing the managerial personality in its context (Vodák and Strišš, 2005).

Environment and its components can create opportunity for an active manager when he removes or lowers barriers. Managerial behavior is neither a mechanistic nor a homogenous response to external pressures but is rather influenced by complex situational different interactions of factors 
(Dill, 1962; Killingsworth et al., 2016). This article follows manager-person-related factors as well as environment contextual factors. Research has shown a high propensity for managers to be active. On contrary even very active managers can face limited chances to overcome constraints. The characteristics of a successful manager is trust in himself (Kahneman, 2012). Psychological aspect may be a key factor influencing managerial behavior in differing environments (Child, 1972). As a result, it is necessary for management theory to incorporate behavioral approach and the role of managers' personality. This means to pay more attention to the social, psychological, and personal characteristics of a manager.

\section{REFERENCES}

BINGHAM, C. B. and HALEBLIAN, J. 2012. How firms learn heuristics: Uncovering missing components of organizational learning. Strategic Entrepreneurship Journal, 6(2): 152-177.

CYERT, M. R. and MARCH, J. G. 1972. A behavioral theory of the firm. Malden, MA: Blackwell Publishing.

DE NISI, A. 2011. Managing Performance to Change Behavior. Journal of Organizational Behavior Management, 31(4): 262-276.

DILL, W. R. 1962. Environment as an influence on managerial autonomy. Administrative Science Qarterly, 2: 409-443.

EMERY, E. and TRIST, E. 2009. Organization change: The Casual Texture of Organizational Environments. San Francisco: John Willey.

ESOGWA NWACHUKWU, C., CHLÁDKOVÁ, H. and ŽUFAN, P. 2017. The relationship between Entrepreneurial orientation, entrepreneurial competencies, entrepreneurial leadership, and firm performance: A proposed model. Trendy v podnikání/Business Trends, 7(1): 3-16.

HAFIZA, M. R. and ISMAILB, K. 2015. The propensity of adapting strategic reactiveness and entrepreneurial management amongst SMEs. Procedia - Social and Behavioral Sciences, 181: 356365.

CHILD, J. 1972. Organizational structure, environment and performance: the role of strategic choice. Sociology, 6(1): 2-22.

KAHNEMAN, D. 2012. Thinking, Fast and Slow. New York: Penguin Press.

KILLINGSWORTH, K. et al. 2016. A Behavioral Interpretation of Situation Awareness: Prospects for Organizational Behavior Management. Journal of Organizational Behavior Management, 36(4): 301321.

KOONTZ, H. and WEIHRICH, H. 2015. Essentials of management: an international, innovation, and leadership perspective. 10 ${ }^{\text {th }}$ Edition. Chennai: McGraw-Hill Education (India) Private Limited.

KORÁB, V. and BUMBEROVÁ, L. 2013. Empirical development taxonomy of micro, small and medium-sized enterprises in South Moravian Region. Acta Universitatis Agriculturae et Silviculturae Mendelianae Brunensis, 59(7): 2021-2031.

KUBANOVÁ, J. and ROUDNÝ, R. 2008. Information Mining from Thin Evaluation Scales. Scientific Papers of the University of Pardubice 13, series D. University of Pardubice.

LAWRENCE, P. R. and LORSCH, J. W. 1967. Organization and environment. Boston: Graduate School of Business Administration, Harvard University.

MANDYSOVÁ, I. 2019. Behavioral Management under different Business Environment Conditions. In: Proceedings of $2^{\text {nd }}$ International conference on Decision making for Small and Medium-Sized Enterprises. Silesian University in Opava, School of Business Administration in Karviná, pp. 149157.

MYŠKOVÁ, R. and DOUPALOVÁ, V. 2015. Approach to Risk Management Decision-Making in the Small Business. Procedia Economics and Finance, 34(C): 329-336.

MINISTERSTOV PRŮMYSLU A OBCHODU. 2019. Počty podnikatelů a živností dle krajů. MPO. [Online]. Available at: https://www.mpo.cz/cz/ podnikani/zivnostenske-podnikani/statisticke-udaje-opodnikatelich/pocty-podnikatelu-a-zivnosti-dle-kraju--225453/ [Accessed: 2019, July 15].

PRED, A. R. 1967. Behavior and location: foundations for a geographic and dynamic location theory. Lund Studies in Geography, B, pp. 27-38.

PROVAZNÍKOVÁ, R. 2009. Financování měst obcí a regionů - Teorie a praxe. $2^{\text {nd }}$ Edition, Prague. Grada Publishing.

SENER, I. 2012. Strategic Responses of Top Managers to Environmental Uncertainty. Procedia Social and Behavioral Sciences, 58: 169-177.

SILVERMAN, D. 1997. Interpreting Qualitative Data. Methods for Analysing Talk, Text and Interpretation. London: Sage.

SIMON, H. A. 1957. A Behavioral Model of Rational Choice. Quarterly Journal of Economics, 69(1): 99118. 
ŠEBESTOVÁ, J. 2007. Analysis of endogenous factors influencing small and medium sized enterprises: The case of the Moravian-Silesian region. Ekonomický časopis, 55(4): 411-424.

VODÁK, J. and STRIŠŠ, J. 2005. Corporate identity as one of the important management activity. Scientific papers of the University of Pardubice. No. 3 Series B. University of Pardubice.

WILLIAMSON, O. E. 1973. Organizational forms and internal efficiency, markets and hierarchies: some elementary considerations. American Economic Review, 3: 316-325.

Contact information

Ivana Mandysová: ivana.mandysova@upce.cz

Jana Kubanová: jana.kubanova@upce.cz 